\title{
História das primeiras instituições para alienados no Brasil
}

\author{
History of the first institutions \\ for the insane in Brazil
}

Ana Maria Galdini Raimundo Oda

Pesquisadora do Departamento de Psicologia Médica e

Psiquiatria (DPMP) e

Professora de Pós-Graduação

da Faculdade de Ciências

Médicas (FCM)

Universidade Estadual de

Campinas - Unicamp

Caixa Postal 2135

13106-970 Campinas - SP - Brasil

anaoda@uol.com.br

Paulo Dalgalarrondo

Livre docente do DPMP da FCM Coordenador do Laboratório de Saúde Mental, História, Cultura e Epistemologia

Universidade Estadual de

Campinas - Unicamp

Rua Frei Manoel da

Ressurreição, 1156

13073-021 Campinas - SP - Brasil pdalga@fcm.unicamp.br
ODA, A. M. G. R; DALGALARRONDO, P. História das primeiras instituições para alienados no Brasil. História, Ciências, Saúde - Manguinhos, v. 12, n. 3, p. 983-1010, set.-dez. 2005.

Este artigo apresenta os resultados de pesquisa sobre a institucionalização dos alienados em cinco províncias brasileiras: São Paulo, Rio Grande do Sul, Maranhão, Pernambuco e Pará. Analisaram-se relatórios dos presidentes dessas províncias durante o Segundo Reinado, entre 1846 e 1889. Nesses documentos a alienação mental é considerada como uma doença especial e se aponta que o lugar dos loucos não é entre os demais doentes, mas tampouco nas cadeias. Notáveis são ainda os registros de pressões da sociedade no sentido de sua internação. Os políticos incorporaram o discurso médico sobre a alienação mental, mas, diante das suas descrições dos Hospícios, evidencia-se a contradição entre um suposto projeto de assistência, baseado em pressupostos pinelianos, e a prática de simples reclusão realmente efetivada.

PALAVRAS-CHAVE: história da psiquiatria - Brasil; política assistencial; internação involuntária; insanidade; Hospício de Alienados Pedro II.

ODA, A. M. G. R; DALGALARRONDO, P. History of the first institutions for the insane in Brazil.

História, Ciências, Saúde - Manquinhos,

v. 12, n. 3, p. 983-1010, Sept.-Dec. 2005.

The article presents research findings on the institutionalization of the insane in five provinces of colonial Brazil: São Paulo, Rio Grande do Sul, Maranhão, Pernambuco, and Pará. Reports by the presidents of these provinces, written during the Segundo Reinado (1846-89), were analyzed. In these documents, insanity is viewed as a special disease, and it is indicated that the mad are not meant to be kept among other ill people, much less in jail. The reports also register societal pressure to have such people committed. These politicians adopted the medical discourse on insanity, but their descriptions of asylums evince the contradiction between an alleged social-assistance project based on suppositions drawn from Pinel and the outright seclusion that was actually practiced.

KEYWORDS: history of psychiatry in Brazil; social assistance policy; involuntary commitment; insanity; Pedro II Hospice for the Insane. 
Se existe classe que mereça uma vigilância esclarecida, benévola e ativa é a dos doidos.

Sigaud, 1835

$\mathrm{T}$ ecendo considerações sobre os problemas causados pelo livre transitar de vários tipos humanos bizarros e amalucados, bem conhecidos de todos, pelas ruas da cidade do Rio de Janeiro, diz o médico francês Joseph-François-Xavier Sigaud (1796-1856):

E quantos idiotas, velhas enfermas e imbecis, não tereis visto de tempos a tempos nos lugares populosos, nos arrabaldes, nos estabelecimentos públicos e nas igrejas? Nós não tratamos aqui dos mendigos, dos leprosos, nem dos bêbados; só lembramos a classe desgraçada dos loucos. (1835, p. 7)

É certo que os citados pedintes, lázaros e bebedores incorrigíveis eram também objeto de preocupações higiênicas da Academia Imperial de Medicina (AIMRJ), da qual Sigaud era um dos fundadores (Academia, 1836). Entretanto, a AIMRJ julgava haver certas peculiaridades a considerar no tratamento dado à "classe desgraçada dos loucos", como já haviam assinalado outros médicos da Sociedade de Medicina predecessora da Academia (Jobim et al., 1831) e continuariam a ressaltar seus ilustrados membros, na defesa da "necessidade da criação de um manicômio ou estabelecimento especial para o tratamento dos alienados", deplorando que estes fossem com freqüência recolhidos à Cadeia Pública ou às enfermarias da Santa Casa de Misericórdia. Em ambos locais, os loucos encarcerados em cubículos estreitos, em condições insalubres e muitas vezes amarrados, compunham cenas dantescas, na vívida descrição de um dos defensores da criação de um manicômio na Corte (De-Simoni, 1839, p. 251).

$\mathrm{E}$, se os loucos pobres que escapavam da reclusão viviam como podiam pelas ruas do Rio, as famílias ricas escondiam cuidadosamente os seus. Sobre o fato, observava o Dr. Sigaud:

Quem acreditará que o número de tais infelizes é considerável e que as famílias ricas que os têm em suas casas nunca tiveram a lembrança de fundar, por uma associação, um asilo em que as regras da higiene pudessem auxiliar com vantagem as prescrições da terapêutica? (Sigaud, 1835, p. 7)

Embora não o fizessem exatamente da forma como sugerira o médico francês, pode-se dizer que, através da Irmandade da Misericórdia, as famílias abastadas cariocas viriam a colaborar na construção do primeiro asilo de alienados brasileiro, destinado sobretudo aos loucos pobres. Bem conhecida é a importante atuação da 
${ }^{1}$ Fundada em Lisboa (1498) a "Irmandade de Nossa Senhora, Mãe de Deus, Virgem Maria da

Misericórdia", no Brasil era conhecida como a "Irmandade da Santa Casa de Misericórdia" Atualmente, a participação das "Santas Casas", agora configuradas como entidades filantrópicas civis sem fins lucrativos, na assistência hospitalar prestada pelo Sistem Único de Saúde (SUS) é ainda expressiva; em 2002 os hospitais filantrópicos eram $27 \%$ das unidades hospitalares credenciadas e detinham $34 \%$ dos leitos hospitalares disponíveis na rede pública.
Irmandade da Santa Casa de Misericórdia da Corte, tanto nas articulações políticas que levaram ao decreto da fundação (1841) quanto na mobilização social em torno da construção do Hospício de Alienados Pedro II, inaugurado em 1852 (Machado et al., 1978; Teixeira, 1997).

Fora da capital imperial, durante o Segundo Reinado (1841-1889), ocorreram movimentos similares de institucionalização dos alienados, dos quais certas particularidades são apresentadas neste artigo. Procuramos assinalar conteúdos recorrentes de discursos oficiais sobre a questão da alienação mental, ou seja, as justificativas invocadas para a criação dos primeiros asilos de alienados e os problemas descritos sobre sua instalação e manutenção, em cinco províncias brasileiras, a saber, São Paulo, São Pedro do Rio Grande do Sul, Maranhão, Pernambuco e Pará.

\section{As Santas Casas e os hospitais nas províncias}

Antes, porém, vale lembrar que, no período em estudo, os 'Asilos', 'Hospícios' ou 'Hospitais' eram locais de hospedagem para aqueles que dependiam da caridade: os órfãos, os recém-nascidos abandonados (chamados 'expostos'), os mendigos, os morféticos e os loucos. Tais hospícios poderiam contar eventualmente com alguma assistência médica, mas sua principal intenção era dar aos necessitados um abrigo, alimentos e cuidados religiosos. Os estabelecimentos destinados ao recolhimento de alienados pobres, portanto, surgiram quase sempre como estruturas asilares das Santas Casas de Misericórdia, bem antes que a psiquiatria existisse como prática médica especializada (Oda \& Dalgalarrondo, 2004).

Herança cultural típica dos territórios de colonização portuguesa, a confraria leiga católica 'Irmandade da Misericórdia' esteve presente nas principais cidades brasileiras desde o século XVI (RussellWood, 1981). Embora inicialmente nem todas as Irmandades brasileiras mantivessem hospitais de caridade, com o passar do tempo, uma de suas principais atribuições tornou-se o denominado "cuidado curativo dos pobres" (Mesgravis, 1976), que se estendeu aos alienados a partir da segunda metade do século XIX. ${ }^{1}$

Observe-se que, então, todas as associações religiosas estavam sob a jurisdição dos respectivos governos provinciais e a eles prestavam contas do funcionamento dos "estabelecimentos pios" que lhes pertenciam e de suas atividades filantrópicas; em contrapartida, dos governos recebiam subvenções.

\section{Os primeiros espaços exclusivos para alienados}

Além do Hospício de Alienados Pedro II, durante o Segundo Reinado foram ainda criadas instituições que se denominavam 
"exclusivas para alienados" em São Paulo, Pernambuco, Pará, Bahia, Rio Grande do Sul e Ceará, como se vê no Quadro 1:

2 Sobre a constituição do alienismo no Rio de Janeiro, veja-se o clássico de Roberto Machado et al., Danação da norma (1978), e o excelente estudo de Magali G. Engel, Os delírios da razão: médicos, loucos e hospicios (1830-1930). Rio de Janeiro: Ed. Fiocruz, 2001. Sobre as relações entre ciência psiquiátrica e política assistencial no Brasil, consulte-se: Ana Teresa A.

Venâncio. Ciência psiquiátrica e política assistencial: a criação do Instituto de

Psiquiatria da Universidade do Brasil. Hist. Cienc. Saude - Manguinhos, v. 10 , n. 3 , p. $883-900$ set.-dez., 2003.

3 Tais documentos foram digitalizados e parcialmente indexados e estão disponíveis on-line no "Projeto de Imagens de Publicações Oficiais Brasileiras" promovido pelo Center for Research Libraries (CRL), uma instituição que congrega várias universidades da América do Norte, além da Library of Congress e da New York Public Library. O Latin-American Microform Project foi patrocinado pela Fundação Andrew W Mellon para produzir imagens digitais de publicações oficiais a partir de cópias em microfilme dos originais.
Quadro I - Primeiros estabelecimentos ditos exclusivos para alienados nas províncias, criados durante o Segundo Reinado

\begin{tabular}{|lcl|}
\hline \multicolumn{1}{|c|}{ Província } & Ano & \multicolumn{1}{c|}{ Estabelecimento } \\
\hline São Paulo & 1852 & $\begin{array}{l}\text { Hospício Provisório de Alienados de } \\
\text { São Paulo (Rua São João). }\end{array}$ \\
Pernambuco & 1864 & $\begin{array}{l}\text { Hospício de Alienados de Recife-Olinda } \\
\text { (da Visitação de Santa Isabel). }\end{array}$ \\
Pará & 1873 & $\begin{array}{l}\text { Hospício Provisório de Alienados } \\
\text { (Belém, próximo ao Hospício dos Lázaros). } \\
\text { Asilo de Alienados São João de Deus } \\
\text { (Salvador) }\end{array}$ \\
Rio Grande do Sul & 1874 & $\begin{array}{l}\text { Hospício de Alienados São Pedro } \\
\text { (Porto Alegre) } \\
\text { Asilo de Alienados São Vicente de Paulo } \\
\text { (Fortaleza). }\end{array}$ \\
\hline
\end{tabular}

Conforme informações de Moreira, 1905, e de Medeiros, 1977.

Ressalte-se que nesses hospícios não havia presença significativa de médicos, até o fim do Império. Somente no início do século $\mathrm{XX}$, com algum custo, os médicos conseguiriam deslocar as poderosas administrações leigas das Santas Casas, bem como as ordens religiosas que prestavam serviços nesses locais, tanto na antiga Corte (Teixeira, 1997), como nas províncias (Medeiros, 1977), instalando-se na direção dessas instituições asilares. ${ }^{2}$

\section{As fontes desta pesquisa}

No presente trabalho, utilizamos um recorte que toma como objeto de estudo um conjunto de documentos oficiais, os relatórios dos presidentes de província emitidos entre 1846 e 1889. Esse tipo de relatório era apresentado regularmente por todos os chefes dos governos provinciais brasileiros às respectivas Assembléias Legislativas, em geral discursando na abertura da primeira sessão anual da legislatura ou nas ocasiões de transmissão do cargo ao sucessor na presidência. Os relatórios registram os discursos em que cada presidente provincial prestava contas aos deputados, ou ao sucessor, dos feitos do governo no ano anterior, e em que fazia considerações sobre as necessidades orçamentárias para o ano vindouro. Muitos deles têm anexos referentes a diversos setores públicos, com mapas estatísticos. ${ }^{3}$

Tomamos, com Le Goff, como ponto de partida a suposição que todo "documento é produzido consciente ou inconscientemente pelas sociedades do passado, tanto para impor uma imagem deste 
${ }^{4} \mathrm{~A}$ intervenção médica somente passaria a ser visível no Hospício da capital paulista depois de decorridos mais de 40 anos de sua fundação, com a entrada de Franco da Rocha para o seu corpo clínico, em 1893. Depois de 1895, com o início das obras do Hospício de Juquery, começaria nova etapa na história da assistência aos alienados em São Paulo. Sobre o tema, veja-se o livro já clássico de Maria Clementina Pereira da Cunha, O espelho do mundo: Juquery, a história de um asilo. Rio de Janeiro: Paz e Terra, 1986 passado, quanto para dizer a verdade" (1998, p. 54, grifo no original). Obviamente, isto é especialmente válido para documentos produzidos no âmbito oficial, do Estado. Diante disso, as fontes foram interrogadas com cuidado, seguindo o conselho de March Bloch (2001, p. 79), com um ceticismo salutar, ou ao menos, com tal intenção, buscando-se sempre a compreensão das condições históricas em que tais documentos foram compostos e das motivações de seus autores.

\section{Trechos selecionados dos relatórios provinciais}

Antes do início das transcrições dos trechos selecionados de 49 relatórios provinciais, apresentamos algumas observações que auxiliam a compreensão do contexto a que se referem os vários discursos oficiais. Para fins de maior clareza, foi feita a atualização ortográfica dos textos dos nomes próprios e dos topônimos.

Numa perspectiva complementar, sintetizamos alguns dados sobre as estatísticas hospitalares presentes nos relatórios analisados.

\section{Província de São Paulo}

Em 14 de maio de 1852, o Hospício Provisório de Alienados foi instalado na capital, numa casa alugada pela província, na Rua São João, e teria, a princípio, apenas nove internos. Funcionou ali até 1864, quando foi transferido para uma chácara na Ladeira da Tabatingüera, de propriedade provincial (Moreira, 1905).

Esse local permaneceu funcionando até 1903; o Hospital-Colônia de Juquery seria inaugurado, ainda parcialmente concluído, em 1898, mas só em 1903 terminaria a transferência dos internos para o novo Hospício, cerrando-se então definitivamente as portas da casa da Tabatingüera (Franco da Rocha, 1912). Os relatórios se referem, portanto, ao Hospício de Alienados em seus dois primeiros edifícios, antes do Juquery. ${ }^{4}$

A seguir, são transcritos trechos de treze relatórios da província de São Paulo, publicados nos anos de 1849, 1852, 1859 (Hospício Provisório da Rua São João); e de 1870, 1871, 1875, 1876, 1878, 1881, 1882, 1885, 1887 e 1889 (Hospício da Tabatingüera).

\section{O Hospício Provisório de Alienados (Rua São João)}

No relatório de fevereiro de 1849, o presidente Vicente Pires da Mota fala de lei aprovada no ano anterior, que previa a construção de uma casa para os loucos: "Para cumprir-se o disposto no artigo $5^{\circ}$ da Lei Provincial ... cumpre calcular previamente o número provável de alienados que deve conter o hospital; exigiram-se informações para servirem de base a esse cálculo; ainda não vieram todas". 
Consta que, até 31 de janeiro de 1849, o governo havia sido informado da existência de 52 alienados, em 19 localidades do interior, sendo 31 homens e 21 mulheres (São Paulo, 1849).

Em 1852, o presidente José Tomás Nabuco de Araújo, anuncia que:

autorizado pela Lei provincial n. 12 de 18 de setembro de 1848, em vigor pela Lei provincial n. 10 de 7 de maio de 1851, por se ter recusado a Santa Casa da Misericórdia desta cidade, estabeleci nesta capital uma casa provisória para os alienados, alugando para o dito fim, e por nove anos ... a casa de Felizardo Antonio Cavalheiro e Silva ... a nova casa está repartida convenientemente, e contém os cômodos e divisão necessários para os loucos furiosos e pacíficos ... esta despesa ... é muito insignificante se vos penetrardes do horror que a todos inspirava a barbaridade com que eram tratados esses infelizes até agora lançados nas cadeias até morrerem, e metidos sem culpa no lugar de criminosos e, entre eles, sofrendo violências que revoltam à humanidade. Para dirigir este estabelecimento nomeei ao alferes Tomé de Alvarenga, bem conhecido por sua probidade e espírito caridoso, com a gratificação de $400 \$ 000$ réis, e encarreguei ao Dr. João Tomás de Melo de curar esses infelizes mediante a gratificação de $400 \$ 000$ réis. (São Paulo, 1852)

O presidente José Joaquim Fernandes Torres, em 1859, já fala da necessidade de aumentar a dotação do Hospício: "seu zeloso administrador, o alferes Tomé de Alvarenga ... mostra com evidência que a dotação daquele Asilo, exclusivamente sustentado pela Província, é insuficiente para suas despesas, já que o número de enfermos tem gradualmente crescido". Adverte ainda o mesmo presidente, com relação ao edifício do Hospício, quanto à "falta de capacidade que oferece para os enfermos, que existem aí aglomerados" (São Paulo, 1859).

\section{O Hospício de Alienados da Ladeira da Tabatingüera}

Onze anos depois, em 1870, o presidente Antonio Cândido da Rocha faz um resumo da história da instalação do Hospício e das precárias condições físicas em que se encontra, já em novas instalações. Refere que, em 1869, estiveram ali 76 internos, cuidados por 1 médico, 1 enfermeiro, 1 enfermeira e 3 guardas, além de 1 cozinheira e 2 serventes; havia ainda o escrivão e o administrador.

Este Hospício, fundado em 1852, tem constantemente lutado com dificuldades que se opõem ao preenchimento dos fins humanitários que os Legisladores da Província tiveram em vista com a sua criação. Estabelecido a princípio em um prédio particular, posteriormente comprado pela Província ... sem a capacidade indispensável para os enfermos, guardas e carcereiros, foi dele 
removido para casa de propriedade provincial, sita no lugar chamado Tabatingüera, onde atualmente se acha ... A Lei n. 29 de 7 de julho do ano passado ... autorizou a mandar levantar a planta e orçamento para um novo Hospício ... esse trabalho vos será presente, e tanto mais urge que o tomeis em vossa ilustrada consideração, quanto é certo que os infelizes recolhidos neste denominado Hospício, sem as precisas condições de higiene, sem um tratamento conveniente, como aconselham os especialistas, dificilmente poderão recobrar a razão. (São Paulo, 1870)

Antonio da Costa Pinto e Silva, o presidente seguinte, é igualmente enfático:

Este estabelecimento ... não corresponde às vistas humanitárias de seus instituidores. Parece que um mau fado, tendo presidido sua criação, ainda até agora não deixou de acompanhá-lo ... É verdadeiramente contristador o aspecto desse edifício público, que já teria desabado sobre os infelizes que ali existem reclusos, se não estivesse cheio de escoras. (São Paulo, 1871)

Diante do estado do edifício, julga o presidente que, nestas circunstâncias, "esse estabelecimento não pode ser outra coisa senão uma casa de reclusão de loucos, mas nunca um asilo de infelizes privados da razão" (São Paulo, 1871).

O presidente João Teodoro Xavier, em 1875, fala das necessidades de ampliação do prédio, para que se facilite:

a completa separação dos sexos, a classificação dos alienados e que ofereçam cômodos para o trabalho, refeitório, enfermarias, prisões seguras e higiênicas, etc. ... Neste momento, lendo o relatório do Dr. Chefe de Polícia, encontro nele informações que confirmam a necessidade de aumento do edifício. De 27 localidades, diz ele, recebeu a comunicação da existência de 112 alienados; e as autoridades locais, sob a pressão das circunstâncias, e apesar das ordens em contrário ... fazem remessa de alguns desses alienados ... forçando indiretamente o Governo a admiti-los naquele estabelecimento. (São Paulo, 1875)

O presidente Sebastião José Pereira apresenta o movimento de enfermos no ano anterior e informa que existiam no Hospício 70 alienados (39 homens e 31 mulheres), em fins de 1875. Mostra ainda um aumento significativo da mortalidade: dos 140 alienados tratados no ano, $45 \%$ faleceram. Assim a justifica:

A mortalidade havida tem explicação: na aglomeração inevitável de grande número de enfermos no edifício que ainda não tem acomodações suficientes; no estado morboso de muitos alienados que falecem logo depois de terem entrado no Hospício; e, principalmente, na varíola que por duas vezes desenvolveu-se 
no estabelecimento. Alguns empregados encarregados do tratamento dos variolosos foram vítimas de sua dedicação, tendo falecido dois enfermeiros e um guarda. (São Paulo, 1876)

Acrescenta ainda observações feitas pelo administrador, Frederico de Alvarenga, que, desde 1868, era sucessor do pai no cargo:

$\mathrm{O}$ administrador indica a conveniência de haver dois médicos, e parece-me razoável, pois é bem difícil poder um só tratar regularmente de 70 enfermos ... Também são dignos de melhor retribuição os enfermeiros, que têm um serviço pesado, e que estão inibidos de ter algumas horas de repouso. (São Paulo, 1876)

O relatório de 1878, ainda de Sebastião Pereira, traz um Anexo com as observações do administrador do Hospício, Frederico Antonio de Alvarenga. Este diz que o Hospício tem tratado “do melhor modo que seus recursos lhe têm permitido um grande número de infelizes atacados de alienação mental - a mais temível das enfermidades, que obriga a segregar do seio da família até os entes mais caros e prediletos". Apresenta o administrador o movimento dos alienados do ano findo, cerca de cem alienados por dia, e frisa que o número de internos "seria quase em dobro se fosse possível atender-se aos constantes pedidos de autoridades do interior para a admissão de alienados" (São Paulo, 1878).

Em janeiro de 1881, o presidente Laurindo Abelardo de Brito assim inicia seu relatório: "Este estabelecimento, que alguém já chamou 'Casa das grandes tristezas', estende seus benefícios a toda a Província ... tratando na proporção de seus recursos os infelizes que perderam a razão" (São Paulo, 1881). Ressalta as ampliações ainda necessárias, pois:

os compartimentos da casa apenas permitem a separação dos sexos e, entre as classes dos enfermos, os tranqüilos dos agitados. Para que o estabelecimento se aproxime dos tipos que a medicina alienista exige, fora necessário ter divisões para agitados, incômodos, imundos e epilépticos, tranqüilos e enfermaria ... Se pretendeis que aquela casa deixe de ser simplesmente uma hospedaria de infelizes para tornar-se verdadeiro hospício em que os enfermos possam recuperar a saúde e com esta o uso da razão, decretai a cota necessária para que ela possa ter um médico especialista. (São Paulo, 1881)

Ainda no mesmo relatório, o Anexo do administrador Alvarenga lembra que o Hospício havia 27 anos vinha tratando "um avultado número de enfermos afetados da mais triste das enfermidades, como é a loucura, contribuindo ao mesmo tempo para a paz e bem estar das famílias dos mesmos, e para a ordem e tranqüilidade da sociedade em geral" (São Paulo, 1881). 
No ano seguinte, o vice-presidente Souza Aranha, Conde de Três Rios, diz do estado precário do Hospício,

Os intuitos de uma sociedade civilizada não ficam satisfeitos com a detenção destes infelizes em número superior à lotação do edifício, presos à mais perigosa melancolia, sem trabalho apropriado e sem possibilidade de cura quando a anormalidade mental chega a um certo grau. Pode haver egoísmo, mas não há caridade ... Se ainda não existe classificação dos alienados, oficinas de trabalho, lugar para recreio, enfermarias higiênicas, casas para banho, duchas, aparelhos e instrumentos que a ciência médica manda aplicar, qual seria o meio de tratamento empregado anteriormente? (São Paulo, 1882)

O presidente José Luiz de Almeida Couto, em 1885, refere que os problemas apontados pelo administrador Alvarenga permanecem sem solução e que o número de internos mantém-se entre "180 a 190 alienados; resultando disto graves inconvenientes para o tratamento dos enfermos e para a salubridade do estabelecimento" (São Paulo, 1885).

Em 1887, o presidente Barão do Parnaíba lembra que o estabelecimento "tem recebido constantes melhoramentos, reclamados pela elevação do número dos enfermos, que cresce com o aumento da população e com outras causas, que levantam discussão entre os profissionais" (São Paulo, 1887). Pela primeira vez, aparece uma crítica às estatísticas do Hospício:

Deixa de apresentar ele uma estatística completa, contendo ... a determinação de domicílio, da idade, da época em que a doença se manifestou, do seu estado, do grau de instrução e da profissão dos alienados. Observa mais que a polícia remete para o Hospício os alienados que lhe são enviados pelas autoridades do interior, as quais, muitas vezes, nem o próprio nome do enfermo sabem, visto aparecerem eles vagando pelas ruas ou estradas e são completamente desconhecidos no lugar. (São Paulo, 1887)

Encerra o Barão do Parnaíba informando que há dois médicos trabalhando no Hospício, o Dr. Inácio Xavier Mesquita no setor dos homens e o Dr. Tertuliano César Gonzaga no das mulheres. Quanto aos empregados refere haver 27 , sendo 13 homens e 14 mulheres. Destes, "destinam-se 8 ao trabalho de cozinha, lavagem de roupa, limpeza e serviços de rua, ficando apenas 19 para o tratamento e vigilância de 260 alienados e para a conservação da ordem e asseio do estabelecimento" (São Paulo, 1887).

O presidente Pedro Vicente de Azevedo, em janeiro de 1889, após apresentar uma tabela comparativa com os dados do Hospício de São Paulo e do Pedro II (1883-1887), preocupa-se em explicar o maior número de óbitos em São Paulo. Recorda que, no Rio de Janeiro, há um Asilo de Mendicidade que recebe muitos alienados: 
Esses alienados são por certo os incuráveis e quiçá os enfermos mais imundos, quais os idiotas, os imbecis, etc., que, pelo seu estado valetudinário, aumentam o número de óbitos. Aqui, pelo contrário, o Hospício recebe os enfermos de toda sorte de moléstias mentais, pela mor parte incuráveis. Assim, os caducos, os paralíticos, os idiotas, os epilépticos, os afetados de delirium tremens e delírio alcoólico em último grau, enfim, todos os alienados que lhe são remetidos do Asilo de Mendicidade, dos Hospitais de Misericórdia, Penitenciária, quartéis e cadeias de toda a Província. É óbvio que, com tal aglomeração de enfermos incuráveis, haverá necessariamente grande elevação no obituário. (São Paulo, 1889)

Das estatísticas referentes ao movimento anual de alienados no hospício, presentes em nove relatórios, pudemos obter o seguinte gráfico, que compara as proporções de quem teve alta - "curados" - daqueles que morreram. O primeiro ano (1857) se refere ao hospício da rua São João e os seguintes (entre 1869 e 1888) àquele da Tabatingüera.

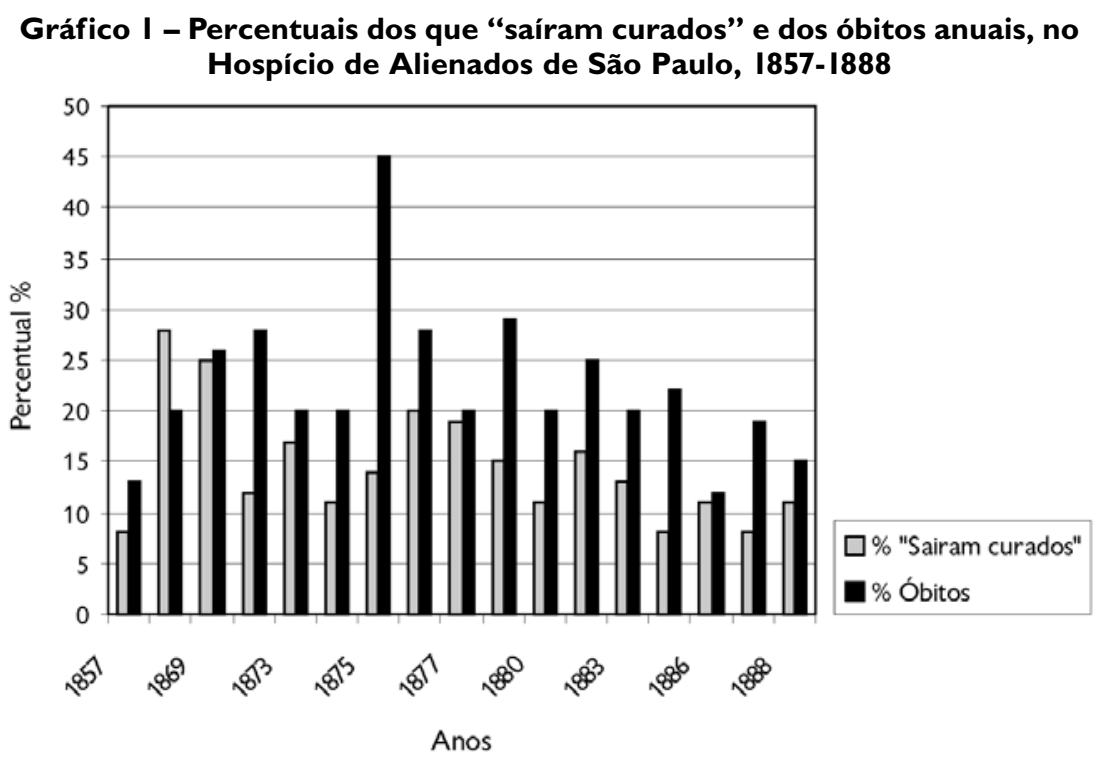

\section{Província de São Pedro do Rio Grande do Sul}

No século XIX, na província de São Pedro do Rio Grande do Sul, os alienados eram alojados pelas Santas Casas ou presos nas cadeias, "onde de decadência em decadência aguardavam a morte" (Moreira, 1905, p. 91). Aquele que é considerado o primeiro hospício de alienados gaúcho, o Hospício São Pedro, foi criado por decreto provincial em 1879, ano em que a província comprou o terreno em que ele se instalaria. Mas, ele seria colocado em funcionamento somente em 1884, sob a direção da Santa Casa (Rio Grande do Sul, 1886). 
5 Sobre o primeiro Hospício gaúcho, veja-se o trabalho de Yonissa Marmit Wadi Palácio para guardar doidos: uma história da luta pela construção do hospital de alienados $e$ da psiquiatria do Rio Grande do Sul. Porto Alegre: Ed. UFRGS, 2002.
Os dez relatórios do Rio Grande do Sul com trechos aqui transcritos são os de 1852, 1859, 1860 e 1862 (alienados na Santa Casa de Porto Alegre) e os de 1864, 1870, 1872, 1877 e 1880 (quando os alienados continuam na Santa Casa, em um prédio anexo, chamado de 'Asilo de Alienados'). No último relatório (1886) se relata sua transferência para o Hospício São Pedro. ${ }^{5}$

Os alienados nas enfermarias da Santa Casa de Porto Alegre

O vice-presidente Luiz Alves Leite de Oliveira Belo, em 1852, inicia o item 'Socorros Públicos' mencionando as atividades da Misericórdia da capital gaúcha:

É o maior, mais completo e mais rico dos estabelecimentos de Caridade, que existem na Província. Sua beneficência não se limita à humanidade enferma: este pio estabelecimento recebe e cria os expostos; procura destino aos meninos e casamento às moças, que tem criado; acolhe e protege os alienados; e os pobres em suas diferentes condições; e tem a seu cargo os enterramentos e o cemitério público ... e o curativo dos presos pobres. (Rio Grande do Sul, 1852)

Joaquim Antão Fernandes Leão, em 1859, informa o movimento da Santa Casa no ano anterior em que, do total de 860 enfermos atendidos, 48 eram alienados (Rio Grande do Sul, 1859). No ano seguinte, o mesmo presidente Fernandes Leão justifica o auxílio concedido para que o Hospital de Porto Alegre reformasse e aumentasse os cômodos ali destinados aos alienados, "para proporcionar cômodos adequados a essa classe de infelizes, por se limitar a 12 o número de células que ali há, sem as condições higiênicas indispensáveis à sua conservação; pelo que mais de uma vez se tem mandado recluir alguns na cadeia de justiça". Refere ainda que o movimento (junho de 1859 a junho de 1860) fora de 804 doentes, dos quais 52 alienados, sendo a maioria inclusa na categoria 'pobres' (46 internos ou 88\%) (Rio Grande do Sul, 1860).

No relatório de 1862, o presidente Francisco de Assis Pereira Rocha, descrevendo o Hospital da Misericórdia da capital, diz que ela possuía "quatro enfermarias distintas: a $1^{\underline{a}}$ destinada aos enfermos do sexo masculino, a $2^{\underline{a}}$ aos do feminino, a $3^{\underline{a}}$ aos inválidos incuráveis e a $4^{\underline{a}}$ aos enfermos particulares. Além destas ... existem as reclusões dos alienados que são ali tratados quando não se acham em estado de quietação, e o não podem ser nas enfermarias gerais". Informa ainda que as obras de um anexo para o 'Asilo de Alienados' estavam adiantadas, mas solicita à Assembléia que autorize a liberação da quantia julgada necessária para que a Santa Casa possa, enfim, concluí-las (Rio Grande do Sul, 1862). 


\section{O ‘Asilo de alienados' anexo ao Hospital da Santa Casa de Porto Alegre}

No relatório de 1864, o presidente Espiridião Elói de Barros Pimentel descreve a solene inauguração de um novo espaço para os alienados:

No dia 2 de dezembro último (1863) foi com toda a solenidade inaugurado este estabelecimento no edifício para ele expressamente construído com as necessárias proporções e sob o mesmo plano do hospital de caridade, de que é continuação. No pavimento superior destinado às mulheres foram recolhidas ... 13 alienadas; o segundo pavimento destinado para os homens recebeu 18 alienados ... No pavimento térreo, que nenhuma aplicação especial por ora tinha, estabeleceu-se uma enfermaria e abrigo, em que fossem recolhidos e tratados em suas enfermidades os mendigos inválidos. (Rio Grande do Sul, 1864)

Em seu relatório de 1870, o presidente João Sertório comenta a inadequação do prédio dos alienados, o mesmo inaugurado havia apenas três anos: "a Santa Casa de Misericórdia é obrigada a ... receber e tratar os infelizes que perdem a razão, não tendo para isso não só os recursos necessários como um edifício conveniente". Sobre o local onde eles eram alojados, o presidente Sertório considera que a "lúgubre instância poderá aumentar-lhes a loucura, mas nunca restituir-lhes a razão" (Rio Grande do Sul, 1870).

Sobre o 'Asilo de Alienados' do Hospital de Caridade, informa o presidente Carvalho de Moraes que estiveram ali 60 alienados, no ano de 1872, ressaltando que ele era o único da província e advertindo que:

O tratamento que nele recebem estes infelizes é inteiramente contrário aos preceitos da ciência e aos princípios de humanidade. Infelizmente, a parte do edifício da Santa Casa que foi reservada ao asilo não oferece proporções para a adoção de melhor sistema de tratamento. $\mathrm{O}$ crescido número que já existe de alienados mostra a urgente necessidade de providências especiais. (Rio Grande do Sul, 1872)

No ano de 1877, o vice-presidente João Dias de Castro lamenta que ainda não se tenha começado o novo asilo, "essa obra toda humanitária, reclamada não só por aqueles que sofrem, como pelas próprias e sublimes máximas que professamos". Também informa que a planta do novo edifício estava pronta, faltando apenas escolher e comprar o terreno, e calcula que seriam necessários 144 contos de réis para toda a obra. Destes, 46 contos já haviam sido levantados sob a iniciativa da Santa Casa, com apoio provincial, através de loterias e donativos. Então, pedindo mais verbas, o 
vice-presidente Dias Castro exorta os deputados: “Só depende de vossa iniciativa a execução desta obra meritória, que os presentes não só aplaudirão, mas também os pósteros bendirão" (Rio Grande do Sul, 1877).

\section{O Hospício São Pedro}

Em maio de 1879, o governo provincial editara o decreto de criação do novo hospício de alienados, e já em dezembro do mesmo ano o presidente Carlos Thompson Flores lançou a sua pedra fundamental, em terreno adquirido nos arredores da capital. No relatório de 1880, são referidas as providências já tomadas para a compra de material de construção, utilizando o dinheiro arrecadado em loterias e donativos. Lembra o presidente que cabia ao corpo legislativo provincial "decretar fundos para que a obra prossiga ... atenta a sua importância e a necessidade de um estabelecimento desta ordem, onde os infelizes privados do uso da razão possam encontrar lenitivo aos seus sofrimentos" (Rio Grande do Sul, 1880).

O presidente José Júlio de Albuquerque Barros, em 1886, relata que haviam sido transferidos os alienados do Hospital da capital para o novo Hospício São Pedro. Este fora inaugurado em 29 de junho de 1884, mas estava pronta apenas a seção do estabelecimento que recebera os 27 alienados da Santa Casa e mais alguns que se encontravam na Cadeia. Esclarece ainda o presidente que a administração do Hospício fora passada à Santa Casa de Misericórdia e que as obras do edifício continuavam, sob direção da província (Rio Grande do Sul, 1886).

\section{Província do Maranhão}

Em São Luís, não se sabe ao certo desde quando, os alienados eram remetidos ao Hospital da Santa Casa, onde permaneceram "pessimamente alojados" (Moreira, 1905, p. 93), até o início do século XX. Apenas em 1882 comprou-se a Quinta da Boa Hora (Maranhão, 1883), onde se iniciaria a construção do primeiro hospício de alienados maranhense, somente inaugurado em 1905 (Medeiros, 1977).

Portanto, os trechos transcritos de cinco relatórios, de 1853, 1870, 1882, 1883 e 1886, referem-se aos alienados em dependências do Hospital da Santa Casa da capital maranhense.

Os alienados na Santa Casa de São Luis do Maranhão

O presidente Eduardo Olimpio Machado, no relatório de 1853, considera que o "hospital da Santa Casa não tem proporções para receber indivíduos atacados de alienação mental, nem os doentes 
desta espécie podem ser nele admitidos sem prejuízo dos outros enfermos" (Maranhão, 1853). A seguir, dizendo ser "esta também a opinião de um homem profissional, o mordomo dos hospitais", transcreve a opinião do Dr. José Maria Barreto:

É prática antiga nesta província ... mandarem-se para o hospital da caridade todos os alienados, e muitas vezes ali vão parar por ordem da polícia. Quando estes enfermos são susceptíveis de cura, concebo que, como os outros necessitados, tenham direito de ser ali recolhidos para se submeterem ao tratamento apropriado; quando, porém, tais moléstias são reconhecidas incuráveis, entendo que não podem, nem devem ser ali conservados porque, além de não haver dentro do estabelecimento quartos próprios para tais doentes, ocupam lugares em que podem ser tratados indivíduos afetados de moléstias curáveis, e fazem diariamente uma gritaria tal, que não só incomoda muito os outros doentes, como pode agravar os padecimentos, e mesmo apressar a morte dos que se acham em perigo de vida. (Maranhão, 1853)

Concluindo, o presidente menciona seus novos planos para os alienados:

Existindo atualmente na Corte um asilo para os alienados - o Hospício de Pedro II - belo e majestoso monumento ... proponho a consignação de uma verba para as despesas com a remessa dos alienados desta província para o Rio de Janeiro. O Governo Imperial, em aviso de 27 de janeiro último, expedido pela Secretaria de Estado de Negócios da Justiça, concedeu a faculdade necessária para se efetuar esta remessa: ainda não usei dela por falta de meios. (Maranhão, 1853)

Apesar da declarada falta de condições, continuou a Santa Casa a receber alienados, subsidiada pelo governo provincial. O relatório do vice-presidente José da Silva Maia, em 1870, dissertando sobre as finanças da Irmandade da Misericórdia, menciona uma quantia que ela, "por falta de crédito, deixou de receber do tesouro provincial pelo tratamento dos alienados".

Já em 1882, o vice-presidente João Paulo Monteiro de Andrade junta ao seu relatório os anexos enviados pela Santa Casa, entre os quais o do mordomo dos hospitais da Irmandade, capitão Manoel Duarte Godinho. Nesse anexo, o capitão manifesta-se contrário à presença de alienados na Santa Casa, pois perturbariam o repouso dos demais doentes, e defende a criação de um hospício específico para os doidos:

Não tem o hospital de caridade acomodações próprias para enfermos desta ordem, e só pelo desejo de prestar algum serviço a esses infelizes ... é que tem levado a Santa Casa a recebê-los, 
aquiescendo assim às instâncias do exmo. sr. dr. chefe de polícia. Em todos os países civilizados se tem levantado edifícios esplêndidos para recolher os seus alienados e, folgo em dizer, no Rio de Janeiro, na Bahia, em Pernambuco e em outras províncias do Brasil já se encontram hospícios de doidos, que nada têm a invejar. (Maranhão, 1882)

\section{A compra da Quinta da Boa Hora}

Em 1883, o presidente José Manoel de Freitas pede a destinação de mais recursos para a Santa Casa, e informa:

Sendo de há muito reclamada a necessidade da aquisição de um prédio para servir de hospital de alienados e que ofereça as necessárias condições ao tratamento destes infelizes ... resolveu a mesa administrativa da Santa Casa comprar a quinta denominada Boa Hora. Como sabeis, de todas as enfermidades que afligem a humanidade, a alienação mental é, por certo, a que mais atenção e socorros reclama da sociedade em geral e do governo particularmente, a quem os sentimentos de caridade impõem o dever de prover o curativo e de proteger a liberdade e segurança desses infelizes. Assim, peço que sejam concedidas [verbas] anualmente à mesma Santa Casa para manutenção e custeio do referido hospício. (Maranhão, 1883)

O presidente João Capistrano Bandeira de Melo, em 1886, refere que 32 loucos estiveram internados no Hospital de Caridade em 1885, sendo que $31 \%$ saíram e $16 \%$ faleceram. Diz ele que o novo Hospício estava "sendo construído pela Santa Casa de Misericórdia, pouco a pouco, com o benefício das loterias concedidas por esta Assembléia". Bandeira de Melo considera a difícil situação das contas da Irmandade da Misericórdia e, falando "no duplo caráter de Presidente da Província e de Provedor da Santa Casa", recorda que a sustentação do novo hospício de alienados "compete especialmente à Província" (Maranhão, 1886).

\section{Província de Pernambuco}

Desde época incerta, os alienados pernambucanos eram alojados em quartos do Hospital da Santa Casa de Recife, denominado Grande Hospital. O hospital de caridade da Misericórdia funcionou até 1845 no Convento dos Carmelitas, depois num prédio conhecido como casa dos Coelhos, até 1861, quando se mudou para instalações especialmente construídas e passou a se chamar Hospital Pedro II (Pernambuco, 1861).

No Hospital da casa dos Coelhos, os alienados eram separados dos demais doentes "em um cárcere estreito e imundo", nas 
palavras de um presidente provincial. Quando, em 1861, os demais doentes foram transferidos para um setor acabado do novo hospital de caridade, na velha casa dos Coelhos restaram apenas os alienados, que lá ficariam até 1864 (Moreira, 1905). Nesse ano, começou a funcionar o Hospício de Alienados de Recife-Olinda, cognominado da Visitação de Santa Isabel, "em uma parte da igreja da Misericórdia em Olinda" (Pernambuco, 1865).

Já em 1874, mostrando-se o Hospício de Olinda insuficiente e inadequado, foi lançada a pedra fundamental de um novo prédio, em um sítio chamado Tamarineira, em Recife; o Hospício da Tamarineira foi aberto em 1883 (Moreira, 1905).

Os trechos transcritos a seguir foram retirados de quatorze relatórios pernambucanos, publicados nos anos de 1846, 1854, 1855 e 1861 (alienados no Grande Hospital ou casa dos Coelhos); de 1865, 1866, 1871, 1873, 1874, 1875 e 1877 (Hospício de Alienados da Visitação de Santa Isabel); de 1883, 1884 e 1888 (Hospício de Alienados da Tamarineira).

\section{Os alienados no Grande Hospital do Recife}

Em 1846, o presidente Antonio Pinto Chichorro da Gama comenta a recente transferência do Grande Hospital para a casa alugada dos Coelhos e aponta a exigüidade do espaço como problema, solicitando a construção de um edifício próprio para o Hospital. Observa ele que "julga a Administração de absoluta necessidade a fatura de uma casa separada da em que se acha o atual hospital para a habitação de alienados" (Pernambuco, 1846).

Em 1854, o presidente José Bento da Cunha e Figueiredo aponta uma nova saída para os alienados:

\footnotetext{
Ouvindo os clamores da administração a respeito do miserável estado em que se achavam os alienados, resolvi-me a remeter para o Hospital de Pedro II na Corte, os 11 que estavam encerrados em um mesquinho quarto do Hospital de Caridade, e mais 5 que se achavam na Cadeia. Foram eles bem recebidos pelo incansável e magnânimo Provedor daquele grande Hospício, que começa já a estender a sua utilidade a diversas Províncias do Império. (Pernambuco, 1854)
}

Já em 1855, não foi possível repetir o expediente, e o mesmo presidente, dando o movimento do Grande Hospital, refere que existiam "9 alienados mendigos que a administração pede que sejam enviados para o Hospício de Pedro II na Corte; mas que eu não posso satisfazer, por obstar-me o Aviso Imperial de 4 de setembro do ano passado, que ordena: que não se remetam alienados sem autorização do Ministério do Império, e sem que sejam considerados curáveis" (Pernambuco, 1855). 
O presidente Ambrosio Leitão da Cunha, em 1861, assinala que quando resolvera mudar para o novo Hospital Pedro II os enfermos a cargo da Santa Casa da Misericórdia, tinha decidido "de conformidade com o parecer dos médicos, baseado nos princípios da ciência e na prática dos países cultos, não os fazer acompanhar pelos infelizes loucos, com quem conviviam no velho Hospital" (Pernambuco, 1861).

Procurando um lugar para abrigar os infelizes alienados, o presidente lembra-se que, tendo as Irmandades da Misericórdia de Olinda e do Recife se unificado, o Hospital de Olinda, restaurado, poderia servir para:

serem nele recolhidos exclusivamente e tratados os loucos de quem a Santa Casa da Misericórdia tomasse conta. Poderia então ali estabelecer-se um Hospital de alienados com grandes proporções, sujeitando-o a conveniente regularidade, e proporcionado assim aos pobres enfermos todos os meios aconselhados pela ciência para a sua cura, ou pelo menos para alívio de seu grande mal. (Pernambuco, 1861)

Os alienados no Hospício da Visitação de Santa Isabel (Olinda)

Finalmente, em 20 de julho de 1864, os alienados foram transferidos para Olinda, como refere o presidente Anselmo Francisco Pereti, no relatório de 1865, em que considera: “O hospício dos alienados acha-se estabelecido no antigo hospital da Misericórdia de Olinda ... e se não é um grande hospital, é sofrível asilo para os infelizes que nele estão recolhidos". Lastima também o presidente a falta de água potável no Hospício, o que obrigava a Santa Casa a comprá-la em barris (Pernambuco, 1865).

Em 1865, foram internados 81 alienados, a maioria mulheres (50, ou $62 \%$ ), conforme o movimento apresentado pelo presidente João Lustosa da Cunha Paranaguá. Ele adverte a Assembléia Provincial de que o estabelecimento "precisa de acomodações para homens, visto que não há mais lugares senão para mulheres" (Pernambuco, 1866).

O número total de internos passara a 122, no decorrer de 1870, número superior à capacidade das acomodações do Hospício e, nesse ano, vemos que a taxa de mortalidade chegou a $25 \%$ dos internados. É disso que fala o presidente Diogo Velho Cavalcanti de Albuquerque, ao iniciar seu relato sobre o Hospício de Alienados, no ano de 1871:

Sem as proporções indispensáveis ao elevado número de enfermos que lá se acham aglomerados, o espetáculo que ali oferecem é contristador, e protesta contra a denominação de Hospício. Não pode haver regime terapêutico nas condições prescritas pela 
ciência; ao contrário, digo pelo que observei, o aspecto do estabelecimento e a aproximação dos loucos das diversas espécies bastarão para entenebrecer sem mais remédio as faculdades mentais de qualquer infeliz que, tendo-as apenas perturbadas, poderia achar perfeita cura, se fosse socorrido convenientemente. A fundação, portanto, de um verdadeiro Hospício seria relevante serviço à humanidade, e peço que considereis neste objeto, sem prejuízo do que reclama o atual. (Pernambuco, 1871)

No ano seguinte, o número de alienados internados chegaria a 120 , a proporção de óbitos aumentaria para $28 \%$. Foi quando Henrique Pereira de Lucena, presidente autor dos relatórios de 1873 a 1875, tomou a si tarefa de levantar meios para a construção de um novo hospício. Solicitando apoio da Assembléia para tal fim, diz ele sobre o seu projeto:

É doloroso, como tive ocasião de presenciar na visita que fiz àquele estabelecimento, ver o estado lastimável a que estão reduzidos [os loucos]. Reconhecendo da mais urgente necessidade a construção de um edifício, onde se procure pôr em prática os meios de cura, aconselhados pela ciência, e que proporcione cômodo e saudável aposento àqueles para qual a mesma ciência se torna improfícua, providenciei no sentido de promover uma subscrição pecuniária e de escolher o local conveniente; e desde já conto com vosso apoio para a realização de uma obra, há tanto reclamada pela caridade e civilização da província. (Pernambuco, 1873)

A coleta de donativos e a construção do Hospício no sítio da Tamarineira

No relatório de 1874, o presidente Pereira de Lucena anuncia os bons resultados da coleta de donativos para a construção do novo prédio para os alienados. Considera ele que seus apelos aos sentimentos humanitários dos pernambucanos tinham sido correspondidos "sem embargo da crise financeira que atravessam a agricultura e o comércio" (Pernambuco, 1874). Apresenta uma lista de valores recebidos e a receber em dinheiro, mais as doações de material de construção, além de muitas jóias e objetos de arte oferecidos para futuros leilões beneficentes em prol das obras do novo Hospício.

No relatório de 1875, Lucena informa o movimento do Hospício de Olinda, que recebera 140 internos no ano. Refere ainda que, tendo sido autorizada a Santa Casa a contratar um construtor para as obras do novo Hospício, escolheu-se o sítio da Tamarineira, onde se assentou, solenemente, a primeira pedra do edifício, em 8 de setembro de 1874. As "espórtulas oferecidas pelos paraninfos da pedra do hospício de alienados" também foram devidamente descritas no relatório (Pernambuco, 1875). 
Examinando a lista de benfeitores do futuro Hospício da Tamarineira, observa-se que as espórtulas vieram, na maior parte, de figuras ilustres: damas da sociedade, nobres, comendadores, eclesiásticos, militares, doutores, magistrados, comerciantes, proprietários e sociedades filantrópicas. Mas também constam algumas doações de gente mais modesta, como as subscrições feitas pela Associação dos Alfaiates e pelos empregados do Cemitério, além do "donativo de uma preta que tirou o prêmio na loteria", uma doação de 50 mil réis, o mesmo dado por certos padres e barões (Pernambuco, 1875).

Entretanto, mais de dois anos depois, encontramos ainda os alienados em Olinda, pois estavam esgotados os recursos da Santa Casa. Então, esperava o presidente Manoel Clementino Carneiro da Cunha que construído este edifício, cessassem "as cenas aflitivas que se observam no hospital de Olinda, e a autoridade poderá então atender aos pedidos que recebe constantemente para tratamento de alienados naquele hospital, não obstante todos os seus defeitos" (Pernambuco, 1877).

\section{O novo Hospício da Tamarineira}

Em 1883, quase nove anos depois de iniciada a sua construção, o presidente Francisco Maria Sodré Pereira relata que os alienados internados em Olinda acabavam de ser transferidos para o novo Hospício da Tamarineira. Faz o presidente algumas ressalvas quanto à adequação do prédio que, embora novo, estaria longe de "satisfazer os requisitos exigidos pela ciência moderna" (Pernambuco, 1883).

Na ocasião, notava esse presidente dois grandes defeitos no edifício da Tamarineira: os esgotos e o encanamento de água. Considerava inadequadas as suas instalações, e previa que haveria problemas futuros de contaminação da água potável. Alertava também para a necessidade de certas obras complementares, como a construção de um muro que cercasse todo o edifício, para evitar a evasão de alienados: "Sem isso, continuarão gradeadas de ferro todas as janelas do edifício, o que hoje é absolutamente condenado, a fim de arredar do alienado toda a suspeita ou desconfiança de coação" (Pernambuco, 1883).

Em fins de 1883, registraram-se 244 internos no Hospício da Tamarineira, assistidos por 2 médicos e 7 'guardas', sendo a taxa de saídas igual à de óbitos, $22 \%$. A profecia do presidente Sodré Pereira demorou pouco a se cumprir, pois, já em 1884, o Hospício apresentava problemas sanitários, apontados pelo presidente José Manoel de Freitas: "O hospício está ficando infeccionado, por causa das exalações do depósito de materiais fecais e os asilados já experimentam os efeitos da água, de má qualidade, da cacimba de que se servem" (Pernambuco, 1884). 
Em 1888, o presidente Joaquim José de Oliveira Andrade informa que concedera licença para um dos dois médicos do estabelecimento, e que por "falta de recursos não está concluído o edifício, o que é urgente e indispensável fazer-se, por ser sempre crescente a entrada de doentes, cujo número já é superior às acomodações do edifício" (Pernambuco, 1888).

\section{Província do Pará}

Ao menos desde 1834, há registros de iniciativas do poder público paraense visando isolar os seus alienados, tendo "em vista afastar os insanos por perigosos à tranqüilidade pública" (Moreira, 1905, p. 93), à época sem intenção de dar-lhes tratamento médico, conforme relatou ter verificado Juliano Moreira em documentos oficiais.

Em 1865, foi construída uma enfermaria exclusiva para alienados no Hospital de Caridade chamado do Senhor Bom Jesus dos Pobres, em Belém. Porém, crescendo o número de internos, a Santa Casa julgou necessário instalar um asilo específico para alienados, e o fez com o auxílio do governo provincial na citada fazenda Tucunduba, num pequeno prédio perto do Asilo dos Lázaros (Pará, 1874).

Esse Hospício na Olaria dos Mercenários, também referido como Asilo ou Hospício de Alienados de Tucunduba, embora inaugurado solenemente em 1873, seria apenas um "depósito sem a mínima condição higiênica, e sem um serviço que se pudesse ao menos chamar de sofrível" (Moreira, 1905, p. 94).

Ainda que, desde 1886, estivesse legalmente autorizada a construção de um novo hospício de alienados, somente depois da proclamação da República o governo mandou executar a obra, sendo o Hospício de Alienados do Marco da Légua inaugurado em 1892 (Moreira, 1905).

Os trechos transcritos são de sete relatórios, de 1867, 1874, 1877, $1879,1884,1886$ e 1889 . O de 1867 se refere à enfermaria de alienados do Hospital de Caridade; os demais, ao chamado Hospício de Alienados de Tucunduba.

\section{Os alienados no Hospital de Caridade de Belém}

Encontramos a primeira menção aos alienados no relatório do presidente Joaquim Raimundo de Lamare. Informa o presidente que o Hospital de Caridade, no ano anterior, atendera 380 enfermos e que ali se sentia "a falta de uma casa para alienados, pela inconveniência e prejuízo que resulta aos outros enfermos, que sejam ali reclusos os que se acham em tal estado" (Pará, 1867). 
Hospício de Alienados de Tucunduba, vizinho dos Lázaros

As referências aos alienados, depois de 1874, vêm sempre acompanhando aquelas relativas aos lázaros, seus vizinhos em Tucunduba. O presidente Pedro Vicente de Azevedo, em 1874, relata que o recém instalado Hospício contava com 15 enfermos e informa ainda:

Este hospício foi criado em março do ano passado ... o seu serviço não está bem regularizado em razão do limitado número de enfermeiros e de não achar-se a provedoria habilitada para realizar os melhoramentos de que ele necessita. Todas as despesas com seu custeio têm sido feitas pelos cofres da Santa Casa, para serem havidas do Tesouro provincial, como se infere das ordens da presidência e da lei que criou o estabelecimento; não foram, entretanto pagas ainda. (Pará, 1874)

Em 1877, o presidente João Capistrano Bandeira de Melo Filho dá o movimento de alienados em Tucunduba no ano anterior, em que passaram pelo Hospício 32 internos, 25\% dos quais saíram e $9 \%$ faleceram. Diz o presidente, sobre o estabelecimento:

Quase contíguo ao Asilo dos Lázaros acha-se o Hospício de Alienados, se tal nome merece a péssima e até bem pouco sólida casa em que estão detentos os atacados de afecções mentais. Há ali carência absoluta de tudo, especialmente dos meios higiênicos e indicados pela ciência para o tratamento dos infelizes loucos. É realmente muito sensível a falta nesta capital de um verdadeiro Hospício. A exemplo do que tem sido feito em outras províncias, cumpre dar os primeiros passos para sua realização, não só recorrendo à caridade pública, como também decretando esta Assembléia uma módica quantia anual para isto. (Pará, 1877)

Mantinha-se semelhante a situação dos 14 alienados ali existentes no início do ano de 1879, descrita pelo presidente José Coelho da Gama e Abreu: "O hospício de alienados ressente-se da falta de consertos urgentes ... Convém que mais alguns cômodos sejam dados àqueles infelizes e mais segurança às células". Como novidade, aparece a seguinte informação: “O pessoal empregado é de um servente, sendo que os demais serviços são prestados por mentecaptos que os podem fazer" (Pará, 1879).

Em 1884, dez anos depois da instalação do Hospício de Alienados de Tucunduba, sua situação era muito ruim, e o presidente Visconde de Maracaju prefere transcrever as palavras do provedor da Santa Casa a respeito:

Se o estado dos lázaros é contristador, o dos alienados é lastimoso, a começar pelo edifício que nenhuma acomodação fornece aos infelizes para ali transportados; compõe-se de 7 células que, com bastante dificuldade, comportam quatro enfermos cada 
${ }^{6}$ Consulte-se: Pinel, Philippe. Traité médicophilosophique sur

l'aliénation mentale ou

La manie. 1997, p. 46 66. Reproduzido de Paris: Cercle du livre précieux, 1965. Facsímile da 1. ed. Paris, Richard, Caille et Ravier, 1801.

Disponível em: gallica.bnf.fr/scripts/ Consultation

Tout.exe?O=N089310

E ainda: Esquirol, Jean-Ettiénne. Des Maladies mentales considérées sous les rapports médical, hygiénique et médicolégal. v. II, p. 1-8, 1995. Reproduzido de Paris: Hachette, Bibliothèque

Nationale, 1975 Reproduzido da 1 . ed. Paris: Baillière, 1838. Disponível em: gallica.bnf.fr/scripts/ Consultation Tout.exe?O=N085089 uma; há porém, ocasiões em que numa só se acham cinco e seis, e isso a pedido de autoridades e para auxiliá-los, que reclamam transportes de enfermos para ali. (Pará, 1884)

Em 1886, o presidente Tristão de Alencar Araripe é breve, porém contundente, em relação ao Asilo de Alienados, dizendo que ali os internos viviam amontoados, "aos três e aos quatro no mesmo aposento, sem a mais rudimentar separação" e ainda que o Hospício "montado pela província e administrado pela Santa Casa, funciona em um edifício que, de asilo e cômodos para alienados, só tem o nome" (Pará, 1886).

Encontramos, em fevereiro de 1889, no relatório do presidente Miguel José de Almeida Pernambuco, pela primeira vez a notícia de um médico a serviço do Hospício de Alienados, que recebera 38 internos em 1888, dos quais saíram $13 \%$ e percentual idêntico faleceu (Pará, 1889).

Pede esse presidente a atenção da Assembléia Provincial para o problema da falta de lugares no Hospício de Alienados, o que obrigara já o governo a proibir a remessa de alienados do interior para a capital. Considera ele que aos poderes públicos não seria "lícito deixar em abandono, nas ruas da cidade e na prática inconsciente de desatinos, os indivíduos acometidos de uma tal enfermidade e nem é compatível com os sentimentos de humanidade recolhê-los às prisões, sem o devido tratamento e onde, por lei, só devem estar os criminosos" (Pará, 1889).

\section{"O Hospício de Alienados, esse triste mas necessário abrigo para o pior dos infortúnios”: discussão e conclusão}

Os relatórios dos presidentes de São Paulo, Rio Grande do Sul, Maranhão, Pernambuco e Pará, quando se ocupam dos alienados, mostram padrões discursivos similares. Neles podem ser identificados os mesmos pontos: a alienação mental é considerada como enfermidade especial; a assistência dada aos alienados nas províncias é inadequada; o lugar deles não é entre os demais doentes, mas tampouco nas cadeias.

Os presidentes, quando se ocupam de aspectos concretos da atenção dada aos loucos reclusos, nos hospícios exclusivos, registram sempre que a quantidade de internos é crescente; que suas vagas nunca são suficientes; que as condições de vida dos internos são péssimas e que as verbas a eles destinadas estão aquém das suas necessidades. Também se repete a esperança numa solução que tudo resolveria: a criação de "hospícios modernos". Evidencia-se que os políticos (alguns deles formados em medicina) incorporaram rapidamente o discurso dos médicos a respeito da alienação mental, baseado em ideais do hospício francês, de Pinel e Esquirol. ${ }^{6}$ 
Verifica-se que o trajeto dos alienados nas províncias estudadas foi similar, indo das enfermarias dos hospitais das Santas Casas aos hospícios exclusivos. Apenas em São Paulo o hospício de alienados não foi precedido de assistência sistemática em hospital de caridade, talvez pela precoce decisão do governo provincial paulista em providenciar-lhes um asilo próprio.

No período abrangido por este estudo, considerando todos os tipos de espaços destinados aos alienados, fossem eles separados fisicamente dos hospitais de caridade ou neles inclusos, sob a denominação de enfermarias, asilos ou hospícios, tivemos seu estabelecimento em épocas próximas; ou seja, iniciados no Pará em 1865, no Rio Grande do Sul em 1862, em Pernambuco, em 1861, no Maranhão em 1853 e em São Paulo em 1852.

Pode-se supor, com relação às cinco províncias estudadas, que assim como, em geral, eram pobres os usuários dos hospitais de caridade, também paupérrimos deveriam ser grande parte dos alienados recolhidos aos hospícios.

Os relatórios evidenciam claramente a contradição entre o discurso que enunciava um projeto de assistência oficial e moderno aos loucos e a prática realmente efetivada com relação aos internos. De fato, trata-se de pessoas pobres submetidas a uma reclusão forçada e a péssimas condições de vida, durante toda a segunda metade do século XIX. Condições que os alienados partilhavam com outros doentes sem posses, como os morféticos, o que pode ser exemplificado no caso do Pará, em que estes eram vizinhos dos alienados, e igualmente obrigados a aceitar o compelle intrare da Caridade, personificada na aliança entre as Santas Casas e os governos provinciais. Ainda, pode-se observar nesses documentos os momentos de transição em que os alienados passam a ser objeto do discurso da Ciência e da intervenção do Estado brasileiro, saindo progressivamente dos domínios da mesma caridade cristã.

Há ainda, nos documentos, claras indicações da existência de uma pressão social no sentido da internação dos alienados, de sua retirada das ruas, ação operacionalizada através das autoridades policiais, nas capitais e no interior das províncias.

AGRADECIMENTOS

Somos gratos à Prof. Dra. Wilma Peres Costa (Unicamp) pela indicação do site dos relatórios provinciais brasileiros. A ela e ao Prof. Dr. Manoel Tosta Berlinck (PUC-SP), agradecemos pelos comentários às primeiras versões deste artigo.
Neste sentido, o caso de Pernambuco aponta exemplarmente como as campanhas de arrecadação de fundos para a construção dos primeiros hospícios de alienados puderam mobilizar diferentes segmentos da sociedade, ainda que obviamente conduzidas pelas elites.

Desta maneira, nossa análise dos documentos indica que, no Brasil, o processo de institucionalização dos alienados foi marcado pela construção de uma opinião pública consensual quanto à necessidade e, sobretudo, quanto à legitimidade de sua reclusão em hospícios próprios. 


\section{REFERÊNCIAS BIBLIOGRÁFICAS}

Relatórios provinciais brasileiros

Center for Research Libraries. Latin American Microfilm Project. Brazilian Government Document Digitization Project. Disponível em: www.crl-jukebox.uchicago.edu acesso em agosto de 2004.

Mensagens dos Presidentes das Províncias. Projeto de Imagens de Publicações Oficiais Brasileiras. Statistical Subject Guide. Reports Listed by Province: Maranhão, Pará, Pernambuco, Rio Grande do Sul e São Paulo. Disponível em: catalog.crl.edu/search/dBrazil/dbrazil/ $1,680,1184, \mathrm{~B} / 1856 \& \mathrm{FF}=$ dbrazil\&3,,15,3,0 acesso em agosto de 2004

Maranhão (província)

Relatorio do presidente da provincia do Maranhão, o doutor Eduardo Olimpio Machado, na abertura da Assembléa Legislativa Provincial no dia 1. de novembro de 1853, acompanhado do orçamento da receita e despeza para o anno de 1854. Maranhão, Typ. Constitucional de I. J. Ferreira, 1853.

Relatorio que sua excellencia o senr. vice-presidente da provincia, dr. José da Silva Maya, apresentou no dia 18 de maio de 1870 perante a Assembléa Legislativa Provincial, por occasião da installação de sua sessão ordinaria. S. Luiz do Maranhão, Typ. de J. M. A. Serrão, 1870.

Falla que o exm. snr. dr. José Manoel de Freitas, presidente da provincia, dirigio á Assembléa Legislativa Provincial do Maranhão, por occasião da installação de sua 1.a sessão da 24.a legislatura no dia 13 de março de 1882; seguida do relatorio com que ao mesmo exm. snr. passou a administração da provincia, o 1.o vice-presidente, conselheiro João Paulo Monteiro de Andrade, em 7 do referido mez. [n.p.] Typ. do Paiz, 1882.

Falla que o exm. sr. dr. José Manoel de Freitas, presidente da provincia, dirigiu á Assembléa Provincial por occasião da installação de sua 2.a sessão da 24.a legislatura, no dia 20 de maio de 1883. Maranhão, Empreza do Paiz, 1883.

Falla com que o exm. sr. conselheiro João Capistrano Bandeira de Mello abrio a 1.a sessão da 26.a legislatura da Assembléa Legislativa Provincial do Maranhão, em 13 de março de 1886. Maranhão, Typ. do Paiz [n.d.]

Pará (província)

Relatorio apresentado á Assemblea Legislativa Provincial por s. exc.a o sr. vice-almirante e conselheiro de guerra Joaquim Raymundo de Lamare, presidente da provincia, em 15 de agosto de 1867. Pará, Typ. de Frederico Rhossard, 1867.

Relatorio apresentado a Assembléa Legislativa Provincial na primeira sessão da 19.a legislatura pelo presidente da provincia do Pará, o excellentissimo senhor doutor Pedro Vicente de Azevedo, em 15 de fevereiro de 1874. Pará, Typ. do Diario do Gram-Pará, 1874.

Falla com que o exm. sr. dr. João Capistrano Bandeira de Mello Filho abrio a $2^{\mathrm{a}}$ sessão da $20^{\mathrm{a}}$ legislatura da Assemblea Legislativa da provincia do Pará em 15 de fevereiro de 1877. Pará, Typ. do Livro do Commercio, 1877.

Falla com que o excellentissimo senhor doutor José Coelho da Gama e Abreu, presidente da provincia, abriu a 2.a sessão da 21.a legislatura da Assembléa Legislativa da provincia do GramPará, em 16 de junho de 1879. Pará, 1879.

Relatorio com que o exm.o snr. general visconde de Maracajú passou a administração da provincia ao 2.o vice-presidente, exm.o snr. dr. José de Araujo Roso Danin, no dia 24 de junho de 1884. Pará, Typ. de Francisco da Costa Junior, 1884.

Falla com que o exm. sr. conselheiro Tristão de Alencar Araripe, presidente da provincia do Pará, abriu a 1.a sessão da 25.a legislatura da Assembléa Provincial no dia 25 de março de 1886. Belem, Typ. do "Diario de Noticias", 1886. 
Falla com que o exm. sr. dr. Miguel José d'Almeida Pernambuco, presidente da provincia, abrio a $2^{\mathrm{a}}$ sessão da $26^{\mathrm{a}}$ legislatura da Assembléa Legislativa Provincial do Pará em 2 de fevereiro de 1889. Pará, Typ. de A. F. da Costa.

Pernambuco (província)

Relatorio que á Assembléa Legislativa de Pernambuco apresentou na sessão ordinaria de 1846, o ex.mo presidente da mesma provincia, Antonio Pinto Chichorro da Gama. Pernambuco, Typ. Imparcial, 1846.

Relatorio que á Assembléa Legislativa Provincial de Pernambuco apresentou no dia da abertura da sessão ordinaria de 1854 o exm. sr. conselheiro Dr. José Bento da Cunha e Figueiredo, presidente da mesma provincia. Pernambuco, Typ. de M. F. de Faria, 1854.

Relatorio que á Assembléa Legislativa Provincial de Pernambuco apresentou no dia da abertura da sessão ordinaria de 1855 o exm. sr. conselheiro dr. José Bento da Cunha e Figueiredo, presidente da mesma provincia. Recife, Typ. de M. F. de Faria, 1855.

Exposição do presidente da província de Pernambuco em $1^{\circ}$ de abril de 1861 . Página de título ausente. Assinado por Ambrosio Leitão Cunha, Recife, $1^{\circ}$ de abril de 1861.

Relatorio com que o exm. sr. desembargador Anselmo Francisco Peretti entregou a administração da província ao exm. sr. dr. Antonio Borges Leal Castello Branco. Recife, Typographia do Jornal do Recife, 1865.

Relatorio apresentado á Assembléa Legislativa Provincial em 1.o de março de 1866 pelo exm. snr. conselheiro João Lustosa da Cunha Paranaguá, presidente de Pernambuco. Recife, Typ. do Jornal do Recife, 1866.

Falla recitada na abertura da Assemblêa Legislativa Provincial de Pernambuco pelo excellentissimo presidente da provincia, conselheiro Diogo Velho Cavalcanti de Albuquerque no dia 1.o de março de 1871. Recife, Typ. de M. F. de F. \& Filhos, 1871.

Falla com que o exm. sr. commendador Henrique Pereira de Lucena abrio a sessão da Assemblêa Provincial no 1o de março de 1873. Pernambuco, Typ. de M. Figueiroa de F. \& Filhos, 1873.

Falla com que o exm. sr. commendador Henrique Pereira de Lucena abrio a sessão da Assembléa Legislativa Provincial de Pernambuco em 1 de março de 1874. Pernambuco, Typ. de M. Figueiroa de F. \& Filhos, 1874.

Falla com que o excellentissimo senhor desembargador Henrique Pereira de Lucena abrio a Assemblêa Legislativa Provincial de Pernambuco em o 1.o de março de 1875. Pernambuco, Typ. de M. Figueiroa e F. \& Filhos, 1875.

Falla com que o exm. sr. doutor Manoel Clementino Carneiro da Cunha abrio a sessão da Assembléa Legislativa Provincial de Pernambuco em 2 de março de 1877. Pernambuco, Typ. de M. Figueirôa de Faria \& Filhos, 1877.

Falla com que o exm. sr. conselheiro Francisco Maria Sodré Pereira abrio no 1.o dia de março de 1883 a Assemblea Legislativa Provincial de Pernambuco. Pernambuco, Typ. de Manoel Figueiroa de Faria \& Filhos, 1883.

Falla com que o exm. sr. presidente, desembargador José Manoel de Freitas, abrio a sessão da Assembléa Legislativa Provincial de Pernambuco no dia 1 de março de 1884. Recife, Typ. de Manoel Figueiroa de Faria \& Filhos, 1884.

Falla que á Assembléa Legislativa Provincial de Pernambuco no dia de sua installação a 15 de setembro de 1888, dirigio o exm. sr. presidente da provincia, desembargador Joaquim José de Oliveira Andrade. Recife, Typ. de Manoel Figueiroa de Faria \& Filhos, 1888.

São Paulo (província)

Discurso com que o illustrissimo e excellentissimo senhor doutor Vicente Pires da Motta, presidente da provincia de São Paulo, abrio a Assembléa Legislativa Provincial no dia 15 de fevereiro de 1849. São Paulo, Typ. do Governo, 1849. 
Discurso com que o illustrissimo e excellentissimo senhor dr. José Thomaz Nabuco d'Araujo, presidente da provincia de São Paulo, abrio a Assembléa Legislativa Provincial no dia 1.o de maio de 1852. São Paulo, na Typ. do Governo arrendada por Antonio Louzada Antunes, 1852.

Discurso com que o illustrissimo e excellentissimo senhor senador José Joaquim Fernandes Torres, presidente da provincia de S. Paulo, abrio a Assembléa Legislativa Provincial no anno de 1859. S. Paulo, Typ. Imparcial de Joaquim Roberto de Azevedo Marques, 1859.

Relatorio apresentado á Assembléa Legislativa Provincial de S. Paulo pelo presidente da provincia, o exm. sr. dr. Antonio Candido da Rocha, no dia 2 de fevereiro de 1870. S. Paulo, Typ. Americana, 1870.

Relatorio apresentado á Assembléa Legislativa Provincial de S. Paulo pelo presidente da provincia, o exm. sr. dr. Antonio da Costa Pinto Silva, no dia 5 de fevereiro de 1871. S. Paulo, Typ. Americana, 1871.

Relatorio apresentado á Assembléa Legislativa Provincial de S. Paulo pelo exm. sr. dr. João Theodoro Xavier, presidente da provincia, no dia 14 de fevereiro de 1875. S. Paulo, Typ. do “Diario", 1875.

Relatorio apresentado á Assembléa Legislativa Provincial de S. Paulo pelo presidente da provincia, exm. sr. dr. Sebastião José Pereira, em 2 de fevereiro de 1876. S. Paulo, Typ. do "Diario", 1876.

Annexos ao relatorio com que o exm. sr. dr. Sebastião José Pereira passou a administração da provincia ao 5o vice-presidente, monsenhor Joaquim Manoel Gonçalves de Andrade. S. Paulo, Typ. do “Diario", 1878.

Relatorio apresentado á Assembléa Legislativa Provincial de S. Paulo pelo presidente da provincia, Laurindo Abelardo de Brito, no dia 13 de janeiro de 1881. Santos, Typ. a Vapor do Diario de Santos, 1881.

Relatorio... 7 jan. 1882. São Paulo (província) vice-presidente (Souza Aranha) [sic].

Falla dirigida á Assembléa Legislativa Provincial de S. Paulo na abertura da 2a sessão da 26a legislatura em 10 de janeiro de 1885 pelo presidente, dr. José Luiz de Almeida Couto. São Paulo, Typ. da Gazeta Liberal, 1885.

Relatorio apresentado á Assembléa Legislativa Provincial de São Paulo pelo presidente da provincia, Barão do Parnahyba, no dia 17 de janeiro de 1887. São Paulo, Typ. a Vapor de Jorge Seckler \& Comp., 1887.

Relatorio apresentado á Assembléa Legislativa Provincial de São Paulo pelo presidente da provincia, dr. Pedro Vicente de Azevedo, no dia 11 de janeiro de 1889. São Paulo, Typ. a Vapor de Jorge Seckler \& Comp., 1889.

São Pedro do Rio Grande do Sul (província)

Relatorio do vice-presidente da provincia de S. Pedro do Rio Grande do Sul, Luiz Alves Leite de Oliveira Bello, na abertura da Assembléa Legislativa Provincial em o 1.o de outubro de 1852. Porto Alegre, Typ. do Mercantil, 1852.

Relatorio apresentado a Assembléa Provincial de S. Pedro do Rio Grande do Sul na 2.a sessão da 8.a legislatura pelo conselheiro Joaquim Antão Fernandes Leão. Porto Alegre, Typ. do Correio do Sul, 1859.

Relatorio apresentado á Assembléa Provincial de S. Pedro do Rio Grande do Sul na 1.a sessão da 9.a legislatura pelo conselheiro Joaquim Antão Fernandes Leão. Porto Alegre, Typ. do Correio do Sul, 1860.

Relatorio aprezentado pelo presidente da provincia do Rio Grande do Sul, desembargador Francisco de Assis Pereira Rocha, na 1.a sessão da 10.a legislatura da Assembléa Provincial. Porto Alegre, Typ. do Jornal A Ordem, 1862. 
Relatório apresentado pelo presidente da província de S. Pedro do Rio Grande do Sul, dr. Espiridião Eloy de Barros Pimentelna $1^{a}$ sessão da 11.a legislatura da Assembléa Provincial. Porto Alegre, Typ. do Correio do Sul, 1864.

Relatorio com que o excellentissimo sr. dr. João Sertorio, presidente d'esta provincia, passou a administração da mesma ao ex.mo sr. dr. João Capistrano de Miranda e Castro, 1.o vicepresidente, no dia 29 de agosto de 1870. Porto Alegre, Typ. do Rio Grandense, 1870.

Falla dirigida á Assembléa Legislativa da provincia de S. Pedro do Rio Grande do Sul pelo presidente, conselheiro Jeronimo Martiniano Figueira de Mello, em a segunda sessão da 14.a legislatura. Porto-Alegre, Typ. do Rio Grandense, 1872.

Falla dirigida á Assembléa Legislativa da provincia de S. Pedro do Rio Grande do Sul pelo 2.o vice-presidente, dr. João Dias de Castro em a 1.a sessão da 17.o [sic] legislatura. Porto Alegre, Typ. do Jornal do Commercio, 1877.

Relatorio com que o exm. sr. dr. Carlos Thompson Flores passou a administração da provincia de S. Pedro do Rio Grande do Sul ao 3.o vice-presidente, o exm. sr. dr. Antonio Corrêa de Oliveira, a 15 de abril de 1880; este ao exm. sr. dr. Henrique d'Avila a 19 do mesmo mez, e falla com que o ultimo abrio a 2.a sessão da 18.a legislatura d'Assembléa Provincial no dia 1.o de maio de 1880. Porto Alegre, Typ. A Reforma, 1880.

Relatório apresentado a s. exc. sr. dr. Miguel Rodrigues Barcellos, $2^{\circ}$ vice-presidente da provincia do Rio Grande do Sul, pelo exm. sr. conselheiro José Júlio de Albuquerque Barros ao passar-lhe a presidencia da mesma provincia, no dia 19 de setembro de 1885. Porto Alegre, Officinas Typographicas do Conservador, 1886.

LIVROS, TESES E ARTIGOS

Academia Imperial de Medicina 1836

Bloch, Marc 2001

De-Simoni, Luiz Vicente 1839

Franco da Rocha, Francisco

Jobim, José Martins da Cruz et al. 1831

Le Goff, Jacques 1998

Machado, Roberto; Loureiro, Angela; Luz, Rogério; Muricy, Kátia 1978

Medeiros, Tácito A. 1977
Sessão de instalação da Academia Imperial de Medicina do Rio de Janeiro (21.12.1835).

Revista Médica Fluminense, ano II, n. 11, p. 23-36, fevereiro.

A observação histórica. In: Apologia da história ou O ofício do historiador. Rio de Janeiro: Jorge Zahar. p. 76-87.

Importância e necessidade da criação de um manicômio ou estabelecimento especial para o tratamento dos alienados. Revista Médica Fluminense, v. V, n. 6, p. 241-62, setembro. (Republicado em Revista Latinoamericana de Psicopatologia Fundamental, v. VII, n. 1, p. 142-59, março, 2004).

Hospício e Colônias de Juquery: vinte anos de assistência aos alienados em São Paulo. São Paulo: s.n.

Relatório da Comissão de Salubridade Geral, da Sociedade de Medicina do Rio de Janeiro, apresentado e aprovado na sessão de 19 de junho (de 1830). Semanário de Saúde Pública, n. 15, p. 77-81, abril.

A história nova.

4. ed. São Paulo: Martins Fontes.

Danação da norma: medicina social e constituição da psiquiatria no Brasil. Rio de Janeiro: Graal. p. 375-492.

Formação do modelo assistencial psiquiátrico no Brasil. Dissertação de mestrado, Universidade Federal do Rio de Janeiro, Rio de Janeiro 
Mesgravis, Laima 1976

Moreira, Juliano 1905

Oda, Ana Maria G. R.; Dalgalarrondo, Paulo 2004

Russell-Wood, A. J. R. 1981

Teixeira, Manoel Olavo 1997

Sigaud, José Francisco Xavier 1835
A Santa Casa de Misericórdia de São Paulo (1599-1884): contribuição ao estudo da assistência social no Brasil.

São Paulo: Conselho Estadual de Cultura. p. 195-98.

Notícia sobre a evolução da assistência a alienados no Brasil.

Arquivos Brasileiros de Psiquiatria, Neurologia e Ciências Afins, v. I, n. 1, p. 52-98.

O início da assistência aos alienados no Brasil ou importância e necessidade de estudar a história da psiquiatria. Revista Latinoamericana de Psicopatologia Fundamental, v. VII, n. 1, p. 128-41, março.

Fidalgos e filantropos: a Santa Casa de Misericórdia da Bahia, 1550-1755. Brasília: Ed. UnB.

Nascimento da psiquiatria no Brasil.

Cadernos IPUB, v. 8, p. 42-78

Reflexões acerca do trânsito livre dos doidos pelas ruas da cidade do Rio de Janeiro. Diário de Saúde ou Efemérides das Ciências Médicas e Naturais do Brasil, v. I, n. 1, p. 6-8, abril. (Republicado em Revista Latinoamericana de Psicopatologia Fundamental, v. VIII, n. 3, p. 559-62, setembro, 2005). 